\title{
Problems of Interpreting Recent Monetary Developments
}

\author{
by DARRYL R. FRANCIS
}

T IS GOOD to be here and to have this opportunity to discuss a topic of paramount importance to those in the business of banking as well as to the public at large. Most economic analysts now believe that monetary developments have a pervasive and significant effect on all types of economic activity. For this reason, I appreciate your invitation to express my views, which I must hasten to admit are not universally held, but on which I have developed a strong feeling over several years of association with what I believe to be the highest quality of empirical research.

This is an especially interesting time to be discussing monetary developments in view of the considerable differences of opinion on how to measure and interpret the developments in the first half of 1973. Some analysts interpret recent monetary actions to have been quite expansionary, indicating an ebullient economy with an intensification of inflationary forces. On the other hand, others have indicated concern over what they deem undue monetary restraint with a likelihood of a recession late this year or early in 1974. I hope I will not add to the confusion by outlining for you my own interpretation of economic developments so far this year and what they may imply for the future. Before doing so, I think it would be useful to review some of the interpretations of recent monetary actions that have received widespread attention and the facts upon which these interpretations have been based.

\section{Bank Credit}

One prominent view of recent monetary developments has centered on the growth of commercial bank

1This address was delivered at the Seventy-Sixth Annual Convention of the Indiana Bankers Association, French Lick, Indiana, June 13, 1973. Data that have become avalable since the presentation was made have been incorporated into this draft.

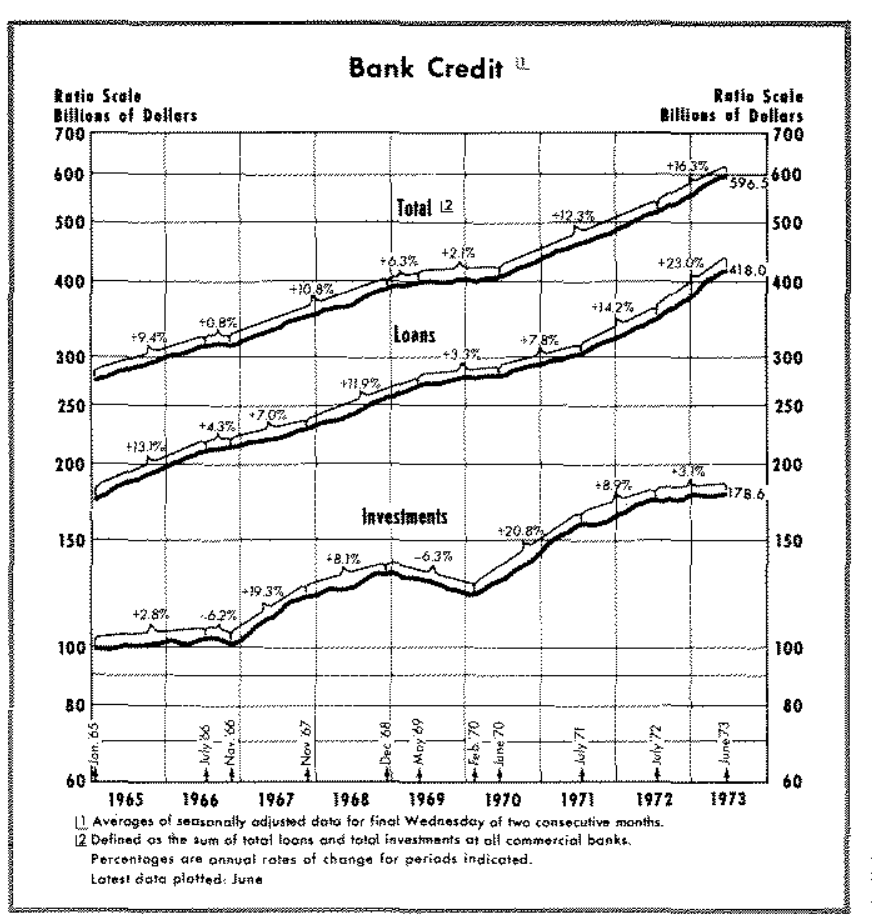

credit as the reliable leading indicator. Those analysts that focus on bank credit have been greatly concerned about the possibility of excessive expansion and a marked step-up in inflationary pressures. Since last July, commercial bank credit outstanding has risen at a rapid 16 percent annual rate. By comparison, during the period from mid-1970 to mid-1972, when aggressive actions - both fiscal and monetary - were taken to stimulate the economy which was recovering from the latest recession, bank credit rose at a 12 percent rate. The average rate of bank credit growth from 1957 to 1970 was about 7 percent.

Actually, bank loans have risen more rapidly in recent months than total bank credit. Total commercial bank loans outstanding have risen at almost a 23 percent annual rate since last July. Investment holdings of banks rose only moderately most of last fall, and 
have declined since January as banks have sought funds to finance the requirements of their business and consumer customers. It has been reasoned that the accelerated expansion of total bank credit this year would supplement the funds available for spending by the public, and therefore should be interpreted as a strong inflationary force in the economy.

The head of Chase Econometric Associates, Inc., the forecasting, analysis, and consulting subsidiary of the Chase Manhattan Corporation, indicated in a newsletter that bank credit developments have been an important element in "the unprecedented increase" in spending. ${ }^{2}$ Increases in bank credit have been much greater than in prior periods of rapid economic expansion. Although the money stock, defined to include currency in the hands of the public and private demand deposits, did slow during the first quarter of 1973, Chase Econometrics noted that banks were able to expand their credit because of an unusual buildup in Treasury deposits in commercial banks (which are not included in the definition of the money stock). Also, banks sold an increasingly larger amount of large negotiable certificates of deposit to raise funds to expand loans. Hence, the huge credit expansion was accomplished at a time of relatively slow growth of the money stock. Chase Econometrics concluded that concentrating on the narrow definition of money, while neglecting what occurred in credit markets, is an acute case of " $M_{1}$ myopia." I would agree that the tightness or ease indicated by a given growth of $M_{1}$ should not be analyzed in a vacuum, but I do not go all the way with the second part of the conclusion namely, that the acceleration of bank credit growth indicates more stimulative monetary actions this year than last.

\section{Interest Rates}

Another approach to assessing monetary developments has been to focus on the cost of credit rather than on volume. Interest rates, particularly short-term rates, have risen substantially since last fall. The rate on bank loans to prime business customers has risen from 51/4 percent last August to $8^{1 / 4}$ percent recently. Yields on Treasury bills, commercial paper, bankers acceptances and other money market instruments have risen even more sharply.

When credit costs rise and funds become less readily available, it is reasoned that businessmen and

2See "The Macroeconomic Forecasts," of Chase Econometrics, Inc., April 25, 1973.

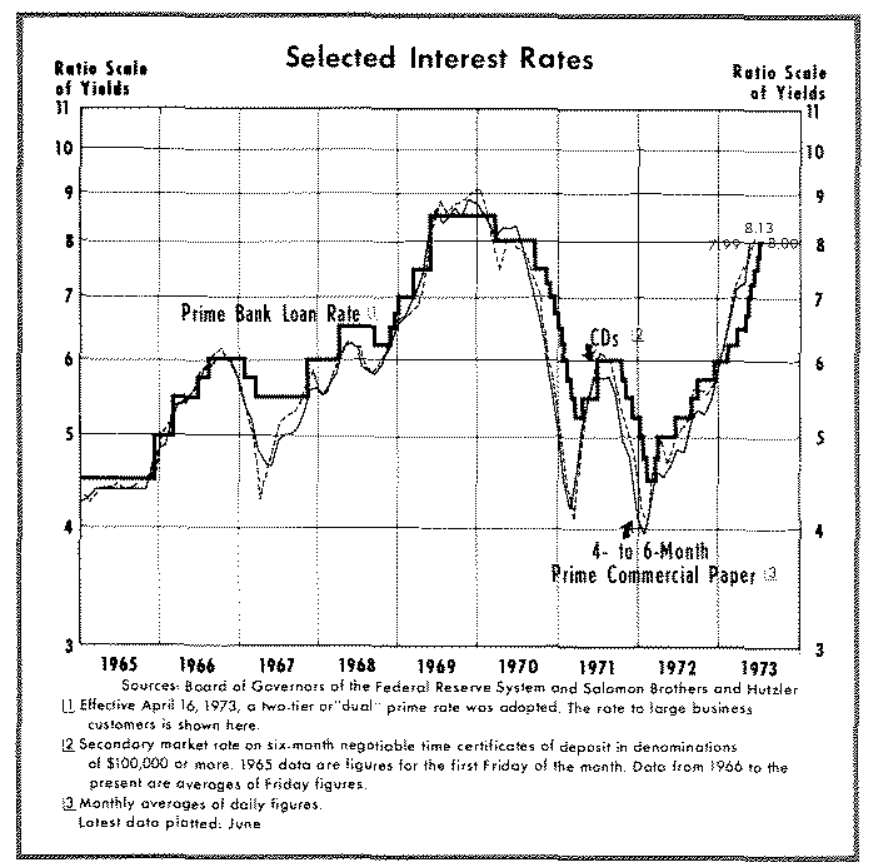

consumers are forced to trim their expenditures. According to this view, the exceptional rate of increase in total spending in the past few quarters would have been even greater if interest rates had not risen. More importantly, higher costs of credit affect future spending plans, and hence, some are becoming concerned that interest rate behavior, possibly even a credit crunch, could foster an economic downturn in the near future. An example of this approach was presented in a recent issue of a national news magazine, where in discussing the task of restraining inflation it was stated, "If this tight money policy is continued for long, . . . it could well lead to oppressive interest rates, a drying up of credit and a dangerous slowdown in the economy comparable to the 1970 recession."

\section{Money Stock}

A third view frequently cited in the press and advisory services has been put forth by some monetarists who have been concerned that monetary actions may have become too restrictive. The money stock of the nation rose at only a 2 percent annual rate from December to March this year. By comparison, money rose at a 7 percent rate on average in the previous two years. It was argued that this sharp slowing in the growth of the narrowly defined money stock, if continued, would lead to a substantial economic slowdown. When people have less money than they

Reprinted by permission from TIME, The Weekly Newsmagazine; Copyright Time, Ine, (May 7,1973 ,) pp. 75-76. 
desire to hold, given current economic conditions, they tend to reduce their rate of spending.

The April 1973 "Monthly Economic Letter" of the First National City Bank states, "In an atmosphere in which more and more people are asking whether credit conditions in 1973 could approach those during the 'crunch' periods of 1966 and 1969 , it is increasingly evident that the commercial banking system is in the midst of a tight squeeze." Loan demand has been unusually great. Yet, "since late 1972, the monetary authorities have refused to supply any more reserves to the banking system. Through December, total reserves - and consequently the money supply continued to rise rapidly because banks sharply in. creased the reserves they were willing to borrow from the Fed. But since early January, banks have been so heavily in debt to the Fed that they have been un. willing to increase their borrowings much more, despite the continued climb in credit demands and in interest rates on bank loans. Consequently, ... reserves available against private nonbank deposits, and the money supply . . have zigzagged sideways."

According to the First National City Bank "Letter", commercial banks have increased their credit largely by aggressive bidding for $\mathrm{CD}$ funds, which results in more total deposits with a given amount of reserves. However, Citibank argues that "the sharp slowdown in money stock growth has led to speculation about the possibility of monetary overkill."

\section{Our View}

Turning to our interpretation at the Federal Reserve Bank of St. Louis of the developments in early 1973, I cannot agree with those who hold the view that the recent rapid growth of bank credit can be taken as an indication that monetary actions have been more stimulative this year than last. Nor can I agree with either the interest rate approach or a strict narrow money approach which argues that monetary developments so far this year have been unduly restrictive. Now, let me see if I can outline for you the problems with each of the three foregoing positions.

It is true that bank credit has been rising at a phenomenal rate in recent months. If this credit were entirely newly-created credit in the sense of being an addition to total credit, then $I$ would be in more agreement with those who are concemed about an acceleration in the growth of bank credit. However, the facts are that a major share of this credit merely reflects a re-routing of the flow of funds from savers

${ }^{ \pm}$pp. 3-4.

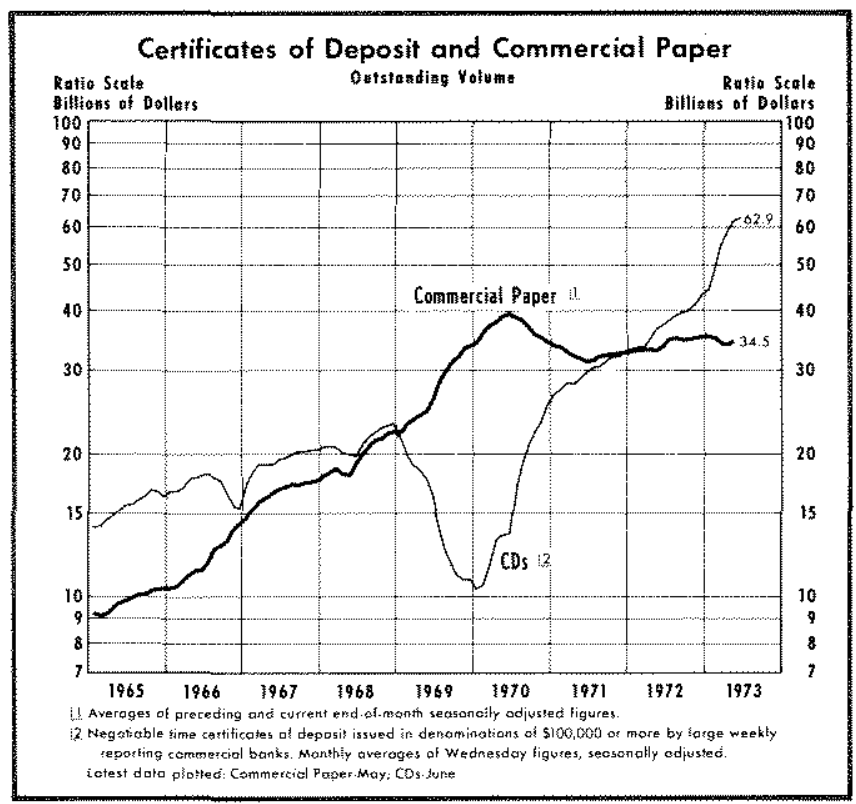

to borrowers through the banking system rather than through other channels.

You may recall that earlier this year the Committee on Interest and Dividends successfully encouraged commercial banks to refrain from increasing interest rates on loans - particularly the prime rate-even though market conditions indicated that such a move was appropriate. As a result many borrowers found that rates offered by commercial banks were more attractive than rates on funds from other sources such as commercial paper. Hence, demand for credit by businesses tended to shift toward banks. In order to meet the loan demand, banks obtained funds, that previously had flowed into commercial paper and other market instruments, by aggressively pricing their large certificates of deposit. Thus, the rapid rise in commercial bank credit was largely offset by a smaller volume of other credit. At the same time, total credit in the economy was not very much affected by the somewhat artificial and temporary upward movement in bank credit.

Fears of an economic downturn based on the recent marked rise in interest rates is similarly only a partial analysis. If the jump in interest rates were solely the result of a monetary contraction, then I would agree that a slowing or a decline in economic activity would likely result. So, let us review the facts behind the interest rate rise.

Interest rates are a price for the use of borrowed funds. Rates are determined by supplies of and demands for funds - just as the prices of housing, food, or other goods are set by demand and supply. There is no factual indication that the supplies of loanable 
funds have been contracting this year. Personal and corporate incomes have risen at rapid rates; the provision of central bank credit, as indicated by the rapid growth of Federal Reserve credit and the monetary base, has not been cut-off; and the growth of commercial bank credit has accelerated from last year.

The strongest upward force on market interest rates late last year and in early 1973 - probably accounting for the bulk of the rise-came from the demand side. Economic activity - stimulated by the rapid monetary expansion of 1971 and $1972-$ has been increasing rapidly. Accompanying the greater activity has been a strengthening in the demand for credit by businesses and consumers. Also, inflationary pressures have intensified as the economy has approached a high level of capacity utilization. In the past it has been observed that when expectations of higher inflation rise, interest rates rise even more. Lenders seek to protect the purchasing power of their funds, while borrowers accept the higher rates in anticipation of repaying in cheaper dollars.

Hence, the higher interest rates are primarily a result of the greater credit demands associated with the rapid expansion of business activity and the rising expectations about future inflation. In short, present interest rate levels are primarily the lagged result of rapid monetary expansion during 1971 and 1972. Current monetary actions have probably played only a minor role in recent interest rate developments. Hence, any overall restraining effect on the economy from the marked rise in market interest rates to date is likely to be slight. Individual borrowers, it is true, have been finding funds increasingly more difficult and more costly to obtain as the demand for credit has been rising even more rapidly than the increasing supplies. But this does not imply that aggregate economic activity is being stifled by inadequate credit.

Most of the time I find myself among those who follow closely the trends of money stock growth in analyzing the impact of monetary actions on the economy. However, I feel the conclusion that monetary actions were unduly restrictive in the first few months of this year because of the slow money growth in that period is unwarranted. For one thing, the time period was relatively brief. Our research shows that normally it takes six to nine months for a significant change in the growth of money to have a measurable impact on real economic activity, and even longer before prices are affected. More importantly, the slow growth of money in those few months was related to several unusual market developments, which were thought to be only temporary since the basic forces underlying

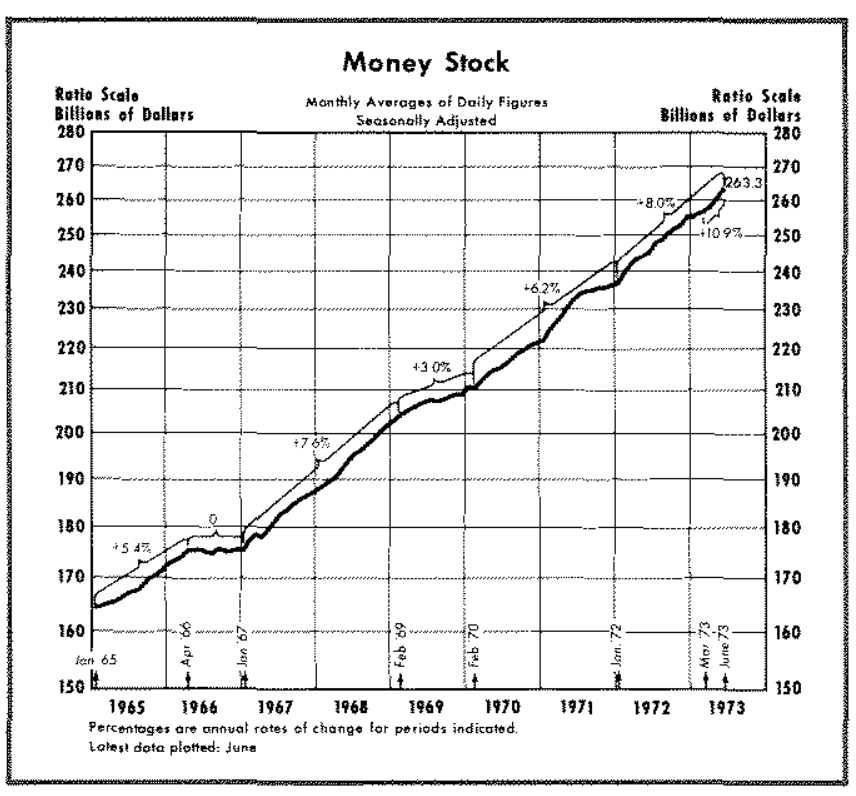

the trend growth of money continued to expand rapidly.

Let's look at what has happened to money growth recently. During October and November last year the growth rate of money slowed somewhat from the rates earlier in 1972, but in December money rose sharply. Then from December to March money rose at an unusually slow 2 percent pace, but since March the stock of money has gone up at an 11 percent rate. In view of the fact that money apparently affects economic activity with a distributed lag over a period of several quarters, it seems more useful to analyze money on balance over the period since sometime last year rather than focus on each of the shorter run fluctuations. As of June the level of money was up an estimated 7.4 percent from a year ago. This was approximately the same rate of increase which prevailed in both the seven-month period from last November ${ }^{5}$ and in the period from fourth quarter 1970 to fourth quarter 1972.

Contrary to the view of some analysts that the slow growth of the narrowly defined money stock in the first quarter was monetary overkill, I have been concerned throughout much of this period that monetary expansion could continue to be excessive. I am strongly persuaded that reduction in monetary stimulus is essential to the elimination of inflationary pressures, and postponement of actions to restrain monetary growth implies that a more costly anti-inflation battle must eventually be waged.

The choice of November 1972 avoids the distortion introduced into rates-of-change calculations from abmomal base periods, such as December or January. 
Contributing to my concern is the observation that the basic forces underlying monetary growth have continued to be expansionary. Since last November, for example, Federal Reserve credit has risen at a very rapid 13 percent annual rate, after increasing just over 7 percent in the previous year. The growth of the monetary base, which underlies the growth of the money stock over a period of several months, has risen at an 8 percent annual rate since last November, the same as in the previous year.

The growth of money slowed in the first few months of this year despite the marked acceleration of Federal Reserve credit and the persistent path of the monetary base. The explanation of this paradox lies in the bunching of several market developments which prevented the rapidly rising base from supporting a proportionately larger growth of money. These market developments appear to have been temporary aberrations, for in the past two months the growth of money has accelerated sharply to a 12.5 percent rate.

An important factor absorbing the monetary base early in the year was an unusual buildup in Treasury deposits in commercial banks. These funds in Treasury accounts are not included in the money stock, but banks are required to hold reserves against these Treasury deposits the same as private deposits. During the international monetary turmoil, the Treasury received a large inflow of funds from foreign central bank purchases of Govermment securities, as these foreign banks sought to invest the dollars accumulated in maintaining exchange rates between their currency and the dollar. Also, early in the year Treasury receipts from personal and corporate income taxes and from agencies such as the Social Security Administration were running well ahead of payments. In late March, Treasury balances at commercial banks averaged about $\$ 11$ billion, up from an average of about $\$ 7$ billion in December. It is well known that the Treasury does not usually hold large idle cash balances, and as these funds are spent, the private money stock has expanded.

Other factors contributing to the slower growth of money relative to base early this year include the rapid growth of CDs and a marked increase in currency in the hands of the public. The growth of CDs at banks absorbs reserves leaving less available to support private demand deposits and other time de posits. Both of these factors are also likely to be temporary, and as they return to more normal patterns, it would be necessary to reduce the rate of

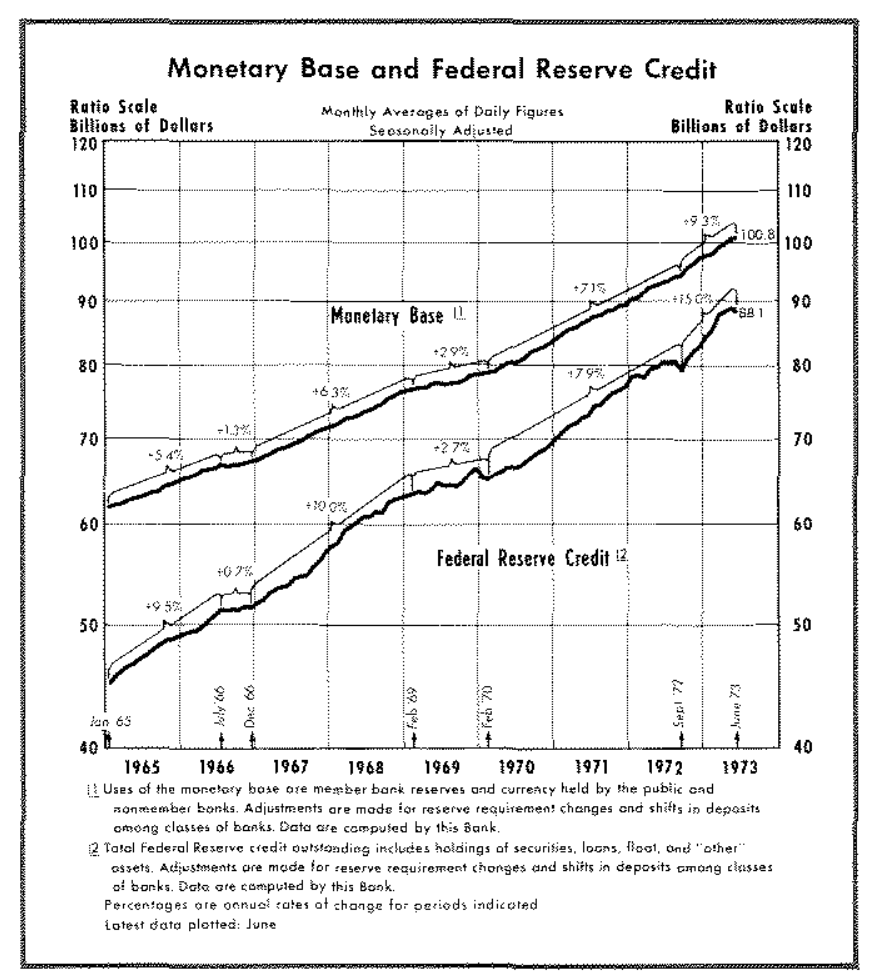

expansion of the monetary base in order to avoid further acceleration in the growth rate of money.

\section{Economic Oullook}

On balance through the first six months of 1973 , the rate of money growth has been somewhat less than the exceptionally high rate of 1972 , but this has not been true for Federal Reserve credit and the monetary base. If one can assume that the growth rate of money from this point is, on average, no more than in the past six months, some slowing in the growth of total spending on goods and services from the unusually rapid growth of the past two quarters can be expected. The rate of GNP growth will probably slow to about 8 percent by year's end, but on average for 1973 the increase should be in the range of 10 to 11 percent. Of that total, it now appears to us that about 6 percent will be in real GNP and about 5 percent in overall price increases for the year.

Moderation of spending is desirable, of course, since the economy is operating at or very near capacity and consequently inflationary pressures have been intensifying. Even so, I would hope that cutbacks in aggregate demand would be gradual; otherwise, production and employment would be seriously affected. Capacity limitations constrain production growth to about a 4 percent rate in the long run, and given our experience with prices so far this year, inflation much below a 5 percent rate on balance for the year is no 


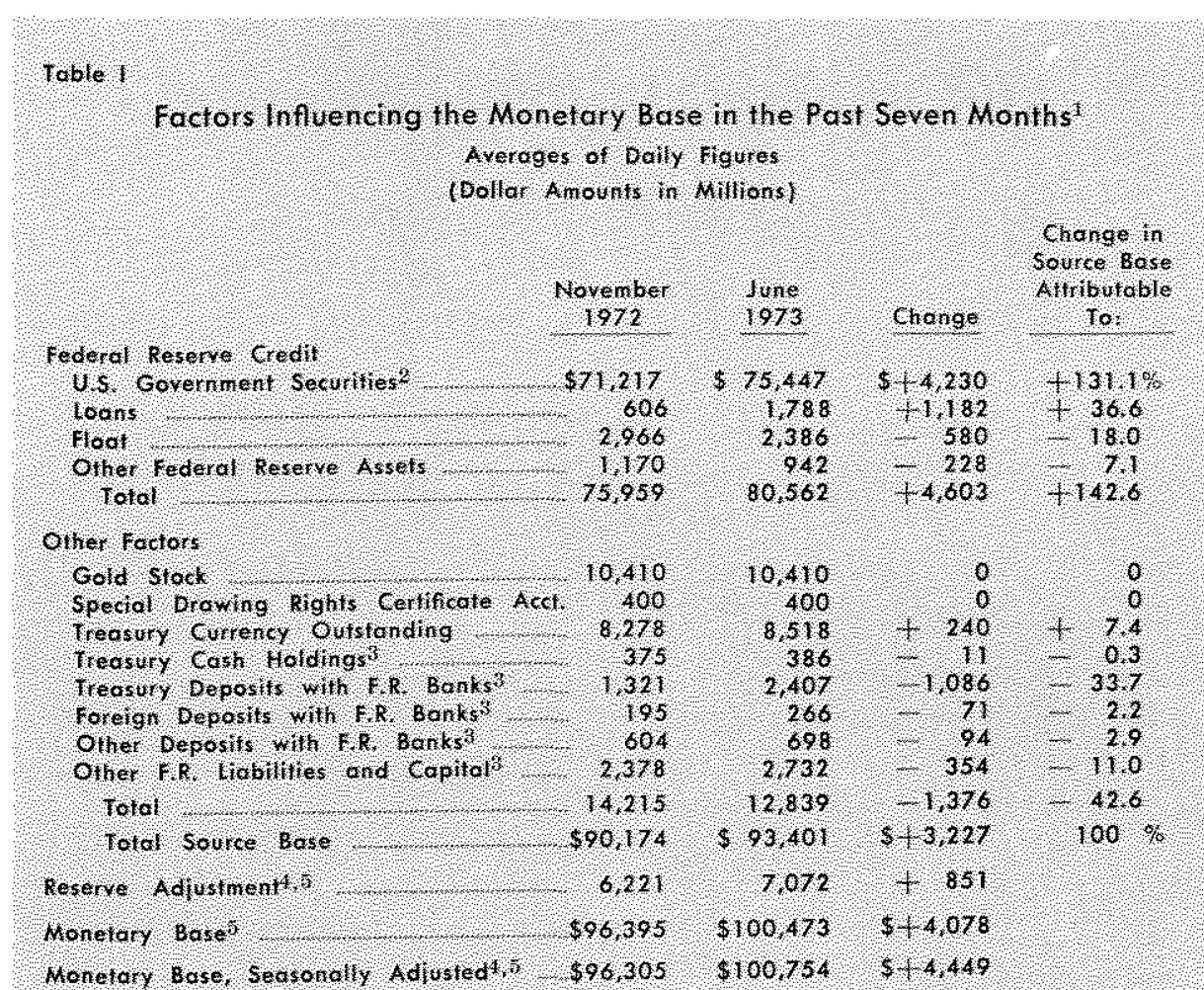

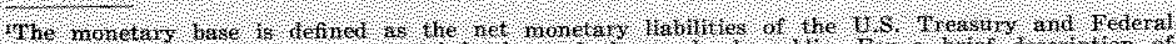

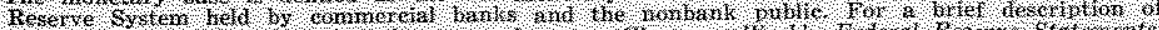

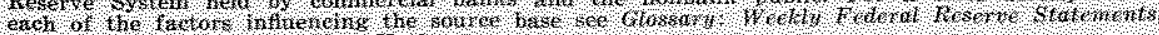

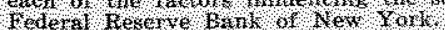

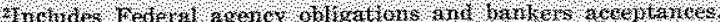

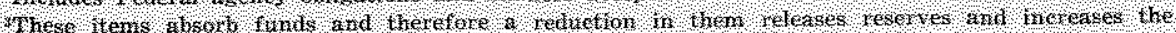

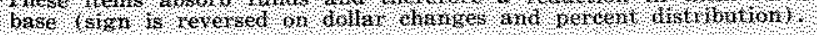

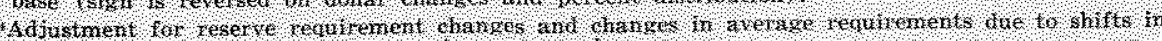

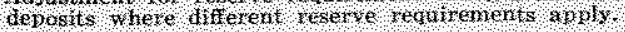

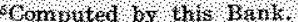

Totals nay not ada due 6 roumding

longer attainable without an unusually severe reduction in production. Over time, the rate of inflation can be reduced; however, if an economic downturn is to be avoided, the transition to stable prices will be a time-consuming process. This will require both the patience and the perseverance that is inherent in the successful avoidance of the traditional massive and abrupt cutback in monetary stimulus when inflation is finally recognized as being out-of-hand. Put another way, achieving stability without suffering a recession is possible, but it will take time and highly disciplined monetary and fiscal actions to get there from here. I believe it can be accomplished, and hope those of us involved in the stabilization decisionmaking process have the patience, perseverance, and the wisdom to achieve this.
Looking into next year, a growth rate of money in the range of 4 to 6 percent would likely be accompanied by a growth of nominal GNP in the range of 7 to 8 percent, and at this point our best judgment is that about half, and more likely less, would be in real output, and the remainder in prices. As you can see, I am not convinced of the necessity for a recession, nor am $\mathrm{I}$ assuming in this analysis any stronger use of economic controls by the Administration or Congress to deal with inflation. ${ }^{6}$ I do not believe that price-wage con trols in and of themselves should be viewed as a basic cure for inflation. Since I hold the view that in the longer run a high level of employment is consistent with relatively stable prices, I continue to advocate achieving a stable rate of monetary growth consistent with that objective. Therefore, assessment of the economic outlook does not assume that controls are either necessary or desirable in order to restrain the rise in prices. A return to more strict controls is again rumored, and they may come. If so, they may affect expectations and market interest rates for a while, and they will certainly affect statistical indicators of economic activity. Under-the-table transactions, black market activity, and product mix changes do not show up in the published price indexes. However, controls can have the appearance of working only if rational fiscal and monetary actions are taken. Otherwise the conflict between real economic forces and the administered economic programs will create a situation which is acceptable to no one.

Prhis presentation was given prior to the June 13, 1973 announcement of a second price freeze followed by Phase IV.

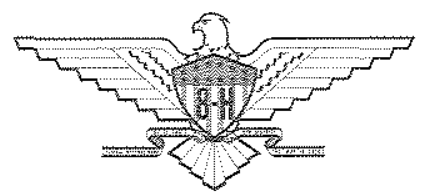

